Portland State University

PDXScholar

$12-2016$

\title{
Parameterizing a Water-Balance Model for Predicting Stormwater Runoff from Green Roofs
}

\author{
Olyssa Starry \\ Portland State Uinversity, ostarry@pdx.edu \\ John Lea-Cox \\ University of Maryland at College Park \\ Andrew Ristvey \\ University of Maryland at College Park \\ Steven Cohan \\ University of Maryland at College Park
}

Follow this and additional works at: https://pdxscholar.library.pdx.edu/honors_fac

Part of the Hydrology Commons, Meteorology Commons, and the Water Resource Management Commons

Let us know how access to this document benefits you.

\section{Citation Details}

Starry, Olyssa; Lea-Cox, John; Ristvey, Andrew; and Cohan, Steven, "Parameterizing a Water-Balance Model for Predicting Stormwater Runoff from Green Roofs" (2016). University Honors College Faculty Publication and Presentations. 2.

https://pdxscholar.library.pdx.edu/honors_fac/2

This Post-Print is brought to you for free and open access. It has been accepted for inclusion in University Honors College Faculty Publication and Presentations by an authorized administrator of PDXScholar. Please contact us if we can make this document more accessible: pdxscholar@pdx.edu. 
1 Parameterizing a water balance model for predicting stormwater runoff from green

2 roofs

3 Olyssa Starry ${ }^{1}$, John Lea-Cox ${ }^{2}$, Andrew Ristvey ${ }^{3}$, and Steve Cohan ${ }^{4}$.

Abstract Crop coefficients $\left(\mathrm{k}_{\mathrm{c}}\right)$ were calculated for three different species of common green roof

6 succulents from March to November in 2011, to parameterize the FAO Penman-Monteith

7 equation for use in a mechanistic green roof water-balance model. Seasonally averaged $k_{c}$ values

8 for each species were then used to predict plant evapotranspiration $\left(E_{T}\right)$ in 2012. The adjusted

9 FAO Penman-Monteith equation predicted total annual $\mathrm{E}_{\mathrm{T}}$ within 3-13 mm, a substantial

10 improvement over model predictions with $\mathrm{k}_{\mathrm{c}}$ set to1, which over-predicted $\mathrm{E}_{\mathrm{T}}$ by $100 \mathrm{~mm}$ or

11 more, depending on species. The adjusted equation was inserted in water balance models which

12 predicted runoff within 2-13\% of measured totals for 2012. This discrepancy may be explained

13 by variability in maximum water holding capacity which is difficult for two dimensional models

14 to predict. Nevertheless, these results provide increased confidence in the use of models to

15 predict stormwater runoff from green roofs and evaluate performance. Monitoring multiple green

16 roof installations with cost-effective sensor networks will increase our ability to identify the key

17 components to enhance green roof function, reduce stormwater runoff, and inform future design.

18 Introduction

19

21 reducing runoff and the burden on aging infrastructure, and decreasing the volume and

22 concentration of pollutants to nearby waterways. The modeling process is very useful for

${ }^{1}$ Assistant Professor, Portland State University Honors College, PO Box 751, Portland OR 97207

${ }^{2}$ Professor, University of Maryland, College Park, Department of Plant Science and Landscape Architecture, 2120 Plant Sciences Building, College Park, MD 20742

${ }^{3}$ Senior Agent, University of Maryland Wye Research and Education Center, 124 Wye Narrows Dr., PO Box 169, Queenstown, Maryland 21658-0169

${ }^{4}$ Professor of Practice, University of Maryland, College Park Department of Plant Science and Landscape Architecture, 2120 Plant Sciences Building, College Park, MD 20742 
23 evaluating the influence of various green roof elements and decisions relative to design intent

24 (Miller, C; Roof Meadow Inc., Philadelphia, PA pers comm). To date, most models of

25 stormwater retention by green roofs have been empirically constructed. Researchers and

26 planners in the United States typically calculate how green roof implementation might affect the

27 "curve number," or an empirically derived line representing a relationship between runoff and

28 rainfall, for different land surfaces (USDA 1986; Carter and Rasmussen 2006; Hawkins et al.

29 2009; MDE 2009). The curve number relates rainfall to runoff for different land surfaces, and

30 urban surfaces are generally assigned 0.89-0.95 depending on soil type; despite some preliminary

31 calculations (Carter and Rasmussen 2006), it is unknown how this number might change with the

32 addition of greenroofs to the urban landscape. Regression models have been developed to

33 predict stormwater runoff from roofs based on storm size in places such as Belgium (Mentens

34 2006) and New York City (Carson et al. 2013). The challenge with empirical models is that

35 their application is limited by the specificity of the data used to construct them (e.g.

36 environmental and biological parameters) and they lack sensitivity to inter-rainfall event

37 processes (Stovin et al. 2012; Nawaz et al. 2015).

38 In contrast, mechanistic models of the green roof water cycle switch the focus to the

39 underlying structures and biogeochemical functions responsible for stormwater storage by these

40 systems. Mechanistic models are usually much more flexible to a wide range of data inputs. To

41 date, most mechanistic models of green roofs are adaptations of the Hydrus 1-3-D (Hilten et al.

42 2008; Palla et al. 2009) or SWMM (She and Pang 2008; Stovin 2010; Burszta-Adamiak and

43 Mrowiec 2013) models for green roof parameters. These have proven to predict aspects of the

44 green roof water cycle well, but they also require substantial parameterization and possibly

45 include too much extraneous information for effective validation with all the green roof designs 
46 and materials (e.g. green roof substrates) that are currently used (Hilten et al. 2008; Burszta-

47 Adamiak and Mrowiec 2013). An alternative modeling approach is simply to continuously

48 estimate the water balance of the green roof system, with the added advantage of utilizing a

49 relatively simple suite of environmental sensors which provide data to inform the stormwater

50 prediction model on a real-time basis (Voyde 2011; Sherrard and Jacobs 2012; Starry et al.,

$512014 a)$

Because rates of plant evapotranspiration $\left(\mathrm{E}_{\mathrm{T}}\right)$ have been directly linked to stormwater

53 retention efficiency (Voyde et al. 2010; Starry 2013), investigating and calibrating $\mathrm{E}_{\mathrm{T}}$ equations

54 used in predictive models is vital to the precision and accuracy of the model outputs. A growing

55 body of research is establishing that standard model equations can be adapted to predict $\mathrm{E}_{\mathrm{T}}$ from

56 green roofs with some success. Plant evapotranspiration is a major component of any water

57 balance model, and the hardest to measure with any precision. Rezaei and Jarrett (2006) tested a

58 number of different predictive $\mathrm{E}_{\mathrm{T}}$ equations for green roof applications and found certain

59 equations worked better under different environmental conditions, in greenhouse studies of

60 Sedum album and Delosperma nubigem. Of the various equations tested (Rezaei and Jarrett

61 2006), four have also been used and verified by others to predict $\mathrm{E}_{\mathrm{T}}$ from experimental mixed-

62 species green roof modules: (a) the Penman and Penman Monteith equation (Feller 2011); (b) the

63 FAO56 version of the Penman-Monteith equation (Hilten et al. 2008; Schneider 2011); (c) the

64 Hargreaves-Samani equation (Hilten et al. 2008), and (d) the Thornwaite equation (Kasmin et al.

65 2010). These equations were also included in a study by Voyde (2011) who tested several

66 additional equations and found the FAO56 version of the Penman-Monteith to be one of the most

67 robust tools (the $\mathrm{FAO} 24$ was preferred) for predicting total $\mathrm{E}_{\mathrm{T}}$ for green roof experiments using

68 D. australe and S. mexicanum. 
The FAO56 equations basically modify the standard Penman-Monteith equations used to

70 predict $\mathrm{E}_{\mathrm{T}}$ by assuming the stomatal conductance and albedo of a theoretical grass reference crop

71 with a height of $0.12 \mathrm{~m}$, an albedo of 0.23 , and a constant surface resistance of $70 \mathrm{~s} / \mathrm{m}$ (Allen et

72 al., 1998). This closely resembles an extensive surface of green, well-watered grass of uniform

73 height, actively growing and completely shading the ground. The fixed surface resistance of $70 \mathrm{~s}$

$74 \mathrm{~m}^{-1}$ implies a moderately dry soil surface resulting from about a weekly precipitation or irrigation

75 frequency. These calculations are subsequently modified by a $\mathrm{k}_{\mathrm{s}}$ coefficient to account for water

76 stress, and a $\mathrm{k}_{\mathrm{c}}$ coefficient to account for physiological adaptations of different plant species

77 relative to the standard reference crop. A key focus of research on adapting $\mathrm{E}_{\mathrm{T}}$ equations

78 (originally designed for agricultural use) for green roofs has been to adjust the calculations for

79 less than well-watered conditions using the $\mathrm{k}_{\mathrm{s}}$ coefficient or similar calculations, as well as

80 adjustments for drought-tolerance (crassulacean acid metabolism, CAM), a trait found in many

81 successful green roof species (Butler 2011, Starry et al., 2014b). One recent study has found that

82 the Thornwaite adjustment (Thornwaite and Mather 1955) works well with the ASCE version of

83 the FAO56 Penman-Monteith equation (DiGiovanni et al. 2013). Another study (Sherrard and

84 Jacobs 2012) successfully used a different adjustment to the same model (based on Guswa

85 2002).

86 Less is known about how to adjust this equation, using crop coefficients, to account for

87 physiological and CAM adaptations by green roof plant species to drought stress. Voyde (2011)

88 references a number of reported $\mathrm{k}_{\mathrm{c}}$-values from different studies globally, which we summarize

89 and supplement in Table 1. Reported values range from 0.52 to 3.25 . Preliminary model runs

90 suggest that a change in crop coefficient from 0.5 to 1 could result in a $15-25 \%$ reduction in

91 predicted runoff from green roofs $<100 \mathrm{~mm}$ in depth (Baraglioli et al. 2008). Some studies 
92 (Table 1) have suggested an overall green roof $k_{c}$ value is near 1 for well-watered conditions,

93 indicating few differences in $\mathrm{E}_{\mathrm{T}}$ rates between Sedum plants and cool season grasses on which

94 the unadjusted FAO56 equations are based. At the same time, adjusting the Penman-Monteith

95 equation for different crops is standard for predicting crop $\mathrm{E}_{\mathrm{T}}$ in the horticultural industry; for

96 example, the City of Riverside (1994) has even produced a manual recommending different kc

97 values for a variety of species. Their recommendation for Sedum rubrotinctum was 0.25-0.35.

98 In fact, many green roof modeling studies appear not to consider a crop coefficient, or

99 do not report any values; this would have the same effect of setting a $\mathrm{k}_{\mathrm{c}}$ value to 1 . Other studies

100 recommend a single, if adjusted, $\mathrm{k}_{\mathrm{c}}$ value over the entire year (Locatelli et al. 2014); Sherrard

101 and Jacobs set their $k_{c}$ value as a constant, but their study only covered the fall season in 2009.

102 In the only freely available green roof modeling program, there is an option to adjust a single $\mathrm{k}_{\mathrm{c}}$,

103 value for the entire model run, and pre-set values range from 0.4-0.7 for succulent and moss

104 combinations (Raes et al. 2006). However, in the FAO guidelines, the mid-season crop

105 coefficients for the most drought-tolerant species (pineapple) is referenced as 0.3 , but is

106 estimated to increase up to 0.5 later in the season (Allen et al. 1998). Green roof Sedum species

107 might be predicted to perform similarly to pineapple, since both species utilize CAM. We found

108 that S. album L. and S. kamtschaticum modulated CAM metabolism to varying extents with

109 different substrate water availability over time, resulting in significantly different rates of $E_{T}$

110 under carefully controlled environmental conditions (Starry et al., 2014b). S. kamtschaticum has

111 now been reclassified as Phedimus kamtschaticus (Fisch. \& C.A.Mey. )'t Hart (t'Hart and Eggli

112 1995). Most studies of crop coefficients for predicting green roof $\mathrm{E}_{\mathrm{T}}$ to date have been

113 conducted over short time periods, with minimal replication; these studies also lack resolution

114 with respect to specific plant species. 
116 differences in $\mathrm{E}_{\mathrm{T}}$ rates for three green roof species merit the use of different crop coefficients in

117 the FAO56 equations for predicting plant $\mathrm{E}_{\mathrm{T}}$, and 2) utilize these rate limiting constants in a

118 green roof water balance model, to evaluate model accuracy and precision for predicting

119 stormwater runoff. In order to address these goals, we calculated $\mathrm{k}_{\mathrm{c}}$ values for three green roof

120 succulent species of varying growth rate and metabolism. These values were used to inform

121 predictions of evapotranspiration and stormwater runoff using a water balance model. This

122 model was calibrated using $2011 \mathrm{k}_{\mathrm{c}}$ values and verified against measured values for 2012. To

123 our knowledge, no previous study has calibrated a green roof model using multiple platform

124 replicates and then rigorously verified the same model with data collected in a subsequent year.

126 Materials and Methods.

\subsection{FAO56 Penman Monteith equation and parameterization}

The FAO56 equation is derived from the Penman Monteith equation (Allen et al., 1998). This equation assumes some constant parameters for a clipped grass reference crop, i.e., a surface resistance of $70 \mathrm{~s} \mathrm{~m}^{-1}$ and an albedo value of 0.23 , and is defined as:

$$
E T_{0}=\frac{0.408\left(R_{n}-G\right)+\gamma \frac{900}{T+273} \mathrm{u}_{2}\left(e_{s}-e_{a}\right)}{\Delta+\gamma\left(1+0.34 \mathrm{u}_{2}\right)} \ldots \text { Equation } 1
$$

where $\mathrm{E}_{\mathrm{To}}$ is reference evapotranspiration, $\mathrm{R}_{\mathrm{n}}$ is net radiation at the crop surface, $\mathrm{G}$ is soil heat flux density, $e_{s}$ is saturation vapor pressure, $e_{a}$ is actual vapor pressure, $r_{s}$ is the canopy surface resistance, $r_{a}$ is the bulk surface aerodynamic resistance, $\Delta$ is the slope of the vapor pressure curve, $\gamma$ is the psychometric constant, $\mathrm{T}$ is the average daily temperature and $\mathrm{u}_{2}$ is average daily 
137 wind speed. A further adjustment is made to account for less than well-watered conditions, by

138 introducing a water stress coefficient, $\mathrm{k}_{\mathrm{s}}$ (Allen et al. 1998). This equation is described as:

$$
k_{s}=\frac{T A W-D_{r}}{T A W-R A W} \quad \ldots . . . \text { Equation } 2
$$

140 where, TAW is total available water, $\mathrm{D}_{\mathrm{r}}$ is root zone depletion $(\mathrm{mm})$, and RAW is water that is

141 readily available to the plant (Allen et al. 1998). The water stress coefficient $\left(\mathrm{k}_{\mathrm{s}}<1\right)$ is then used

142 in conjunction with a second coefficient, the crop coefficient, $\mathrm{k}_{\mathrm{c}}$, accounting for species-specific

143 differences in $\mathrm{E}_{\mathrm{T}}$. The crop coefficient, $\mathrm{k}_{\mathrm{c}}$ is calculated as the ratio of $\left(\mathrm{ks}^{*} \mathrm{E}_{\mathrm{To}}\right)$ to actual $\mathrm{E}_{\mathrm{T}}$. For

144 seasonal crops, different values are typically assigned throughout the year for changes in growth

145 (primarily changes in leaf area and phenological stage of development).

146 Data from a study of Sedum album and Phedimus kamtschaticus in controlled

147 experimental chamber environments (Starry et al., 2014b) was used to parameterize this

148 equation. Wilting point, needed to estimate TAW for all species was set at $0.05 \mathrm{~m}^{3} \cdot \mathrm{m}^{-3}$ based

149 on these results, even though the plants did not wilt or defoliate at this very low soil moisture

150 content, even after 14 days without watering. However, at this soil moisture content, both

151 species had ceased to fix more carbon than they were respiring, indicating moderate to severe

152 water stress. Total available water is defined as the difference between field capacity and

153 wilting point (Allen et al. 1998). We define field capacity (FC) as the VWC observed after any

154 runoff-producing event for all experimental platforms. Field capacity was adjusted continuously

155 based on environmental parameters described in the results section below. The value of readily

156 available water was set to equal zero (0) in equation 2. The justification for doing this is that

157 since green roof substrates typically drain very rapidly, there are very few instances once field

158 capacity is achieved, where one might expect $\mathrm{E}_{\mathrm{T}}$ would not be influenced by VWC.

159 Interestingly, by setting RAW to 0 equation 2 is simplified to the Thornwaite adjustment 
(Thornwaite and Mather, 1955).

\subsection{Data collection}

Experimental platforms for $E_{T}, V W C$, and runoff verification:

Eighteen experimental green roof platforms $\left(1.31 \mathrm{~m}^{2}\right.$ measured along interior margins $)$ were constructed and instrumented at the University of Maryland, College Park campus from May July, 2010 (Figure 1), located in USDA crop zone 6b. Platforms were constructed and maintained according to FLL standards (FLL, 2008). Platforms consisted of a $12 \mathrm{~mm}$ plywood decking covered with EPDM waterproofing membrane, a protection fabric, drainage layer, filter fabric (Conservation Technology, Baltimore, MD) and a baked clay substrate (M2 Stancills, Perryville, MD). Initial bulk density of the substrate was $0.75 \mathrm{~g} / \mathrm{mL}$, with $8 \%$ of particles less than $0.5 \mathrm{~mm}$; $\mathrm{pH}$ was 7.2 , and organic matter content was $3.8 \%$ by mass (Pennsylvania State University, 2010). Two platforms were constructed and left as roofing membrane-only controls; these platforms were used to ensure that equipment measuring water inputs and outputs were functioning correctly and to provide some data on how standard flat roofs might perform under the conditions of this study. The remaining sixteen experimental platforms were planted with 4 replicate treatments of either S. album, P. kamtschaticus, or S. sexangulare L., or left unplanted, in a completely randomized design (Starry, 2013). The unplanted platforms were used as controls in another experiment as well as in this study to determine the relationship between environmental parameters and field capacity.

All platforms drained into a gutter mounted on the lower side of each platform (Starry, 2013) that drained directly into a 40mL double-tipping rain gauge (TB-4, Hydrological Services, Lake Worth, FL). Runoff data from these rain gauges was collected at 1-minute resolution using a CR-10 data logger and two SW8A multiplexers (Campbell Scientific, Logan, UT). The logger 
184 program included an adjustment to the calibration to account for water loss during very high

185 intensity events (Hydrological Services, Lake Worth, FL). Four substrate moisture and

186 temperature sensors (5TM; Decagon Devices, Inc) were deployed in the center of the four

187 quadrants of each of 16 experimental platforms. The sensors ( $\mathrm{n}=16$ per treatment) were

188 positioned so that the sensor blades faced upslope, and oriented vertically (thinnest side up) to

189 the roof surface, to minimize any interference with rainfall. Sensors were calibrated to the

190 specific green roof substrate used and at various times throughout the study, to ascertain

191 variations in sensor performance (Starry 2013). Evapotranspiration was calculated as the

192 difference in average substrate moisture content each day and assumed to be negligible during

193 rain events. Thus, $\mathrm{E}_{\mathrm{T}}$ was not measured on rainy days in which the moisture content increased.

194

195

196

Environmental data collection.

All environmental and soil moisture data were logged and transmitted using radio

197 dataloggers (EM50R; Decagon Devices Inc., Pullman WA). Air temperature and relative

198 humidity (VP-3 sensor), wind speed (Davis cup anemometer), solar radiation (PYR, total

199 radiation pyranometer) and rainfall (ECRN-100 tipping rain gauge) were continuously collected

200 by a weather station at the study site during 2011 and 2012 (Starry 2013).

201 Sensor data was measured every minute and the 5-min averages logged by the EM50R

202 nodes for the environmental (weather) data and the substrate moisture (5TM sensor, $\mathrm{n}=16$ ) data

203 for green roof species ( $n=4$ platforms per species). Data were transmitted and downloaded via a

204 Decagon (RM-1) radio base station in the University of Maryland, College Park (UMCP)

205 greenhouse complex, which was connected to a dedicated computer. Data were downloaded and

206 viewed whenever necessary using DataTrac software v.3.2 (Decagon Devices, Inc.), and from

207 anywhere on the web using Logmein (Woburn, MA) software. More details regarding the 
experimental set-up and specific sensor numbers can be found in Starry 2013.

209

210

211

212 which was set at 5 percent VWC (based on results from Starry et al., 2014). Root zone depletion

213 was estimated using daily averages of measured substrate moisture. Next, $\mathrm{k}_{\mathrm{c}}$ was calculated as

214 the ratio of $\left(\mathrm{k}_{\mathrm{s}} * \mathrm{E}_{\mathrm{To}}\right)$ to actual $\mathrm{E}_{\mathrm{T}}$, averaged for all platforms of the same species for any given

215 day. Since $\mathrm{k}_{\mathrm{c}}$ values are not well-defined for green roof species, they were estimated after

216 estimating $\mathrm{k}_{\mathrm{s}}$, (Figure 3). This was done to eliminate variation due to known relationships

217 between $\mathrm{k}_{\mathrm{s}}$ and VWC before attempting to explain unknown variation due to $\mathrm{k}_{\mathrm{c}}$. These estimates

218 of $\mathrm{k}_{\mathrm{c}}$ were averaged by season during 2011 for each species, where spring was defined as 1

219 March - 31 May, summer as 1 June - 31 August, and fall as 1 September through 30 November.

$220 \quad$ Once $\mathrm{E}_{\mathrm{T}}$ and associated $\mathrm{k}_{\mathrm{c}}$ and $\mathrm{k}_{\mathrm{s}}$ corrections were established, these values were further

221 verified by being incorporated into a green roof water balance for 2012 to predict runoff by

222 setting precipitation $(\mathrm{P})$ equal to $\mathrm{E}_{\mathrm{T}}$ plus change in storage, or substrate VWC, plus runoff $(\mathrm{R})$

223 plus interception (I). We set canopy interception at $10 \%$ of total rainfall for all species, since

224 very few measures of interception for Sedum species have been reported, but preliminary work

225 suggests this is reasonable considering the structure and density of most Sedum canopies

226 (Lotteau, 2006). The model was run on a daily time-step whereby the VWC from the previous

227 time-step was used to estimate $\mathrm{k}_{\mathrm{s}}$. For comparison with our 2011 estimates of $\mathrm{k}_{\mathrm{c}}$, we also ran the

228 model using $\mathrm{k}_{\mathrm{c}}=1$, the average of 2011 and $2012 \mathrm{k}_{\mathrm{c}}$ values (established as described above for

229 2011), and a constant kc value (0.38, the average of all $\mathrm{k}_{\mathrm{c}} \mathrm{s}$ for both years). 


\section{$231 \quad$ Results and Discussion}

\section{$232 \quad$ 3.1 Field Capacity}

233 Field capacity (FC) is key to predicting changes in storage in this model. For each

234 experimental platform, field capacity was measured as the average VWC on the day after the end 235 of a rain event. Previous analyses (Starry 2013) had shown that the VWC was fairly constant in 236 the hours following a rain event regardless of planting treatment, so FC was calculated at the 237 same time for each treatment. An empirical relationship between FC and days since the previous 238 storm event (dpe), total daily precipitation (tdp) and average daily temperature (adt) was 239 established by fitting a stepwise multiple regression to the 2011 data, and using this to predict 240 FC in 2012 (Figure 2). A logistic regression (SAS, phreg) compared input variables based on 241 their chi-squared scores. Storm size (tdp) and temperature (adt) had the highest scores (24 and

24235 respectively); antecedent moisture (dpe) score was the lowest at 15 . Other parameters such as 243 storm duration were rejected from the model due to low chi squared scores $($ score $<5)$.

244 This information on field capacity was then used to calculate the $\mathrm{k}_{\mathrm{s}}$ term in the FAO Penman 245 Monteith equation.

$246 \underline{3.2}$ Actual vs. Estimated Evapotranspiration ( $\left.\underline{\mathrm{E}}_{\mathrm{To}_{\mathrm{o}}}\right)$.

247 In 2011, $1012 \mathrm{~mm}$ of rain were recorded. This included 304mm from tropical storm Irene 248 during the week 8/28/11 - 09/2/15. Excluding this 'outlier' rain event, runoff totaled 474, 430, 249 and 419mm for S. album, $P$ kamtschaticus, and $S$. sexangulare platforms respectively.

250 Differences in rates of $\mathrm{E}_{\mathrm{T}}$ among species were also evident, though not statistically significant.

251 In 2011, the highest total $\mathrm{E}_{\mathrm{T}}$ at $183 \mathrm{~mm}$ could be attributed to $S$. sexangulare compared to $147 \mathrm{~mm}$ 252 for S. album and $162 \mathrm{~mm}$ for P. kamtschaticus. Figures 3(a-c) illustrate the relationship between 
253 actual $\mathrm{E}_{\mathrm{T}}$ and estimated $\mathrm{E}_{\mathrm{To}}$ for these three green roof species during 2011. The FAO56 equation

254 consistently over-predicted rates of $\mathrm{E}_{\mathrm{T}}$ for these three plant species. This disparity was greatest

255 during the summer months, when predicted daily $\mathrm{E}_{\mathrm{T}}$ rates were nearly triple measured rates.

$256 \quad 3.3$ Calculating water stress $\left(\mathrm{k}_{\underline{s}}\right)$ and crop coefficients $\left(\mathrm{k}_{\mathrm{c}}\right)$

257 Our estimates of ks were above $80 \%$ for all species for a majority of the time in both

2582011 and 2012. However, during times of drought, especially in early spring of 2012, we noted

$259 \mathrm{k}_{\mathrm{s}}$ values approaching zero for P. kamtschticus and S. sexangulare as moisture content was

260 reaching wilting point; ks for S. album only approached $20 \%$ during this time due to wetter

261 substrate presumably related to slower rates of evapotranspiration. Figure 4 shows the large

262 variation in daily $\mathrm{k}_{\mathrm{c}}$ estimates by species for non-rainy days in 2011 . The closer the value of $\mathrm{k}_{\mathrm{c}}$ is

263 to 1, the greater the similarity in $\mathrm{E}_{\mathrm{T}}$ between the species in question and the reference cool

264 season grass $\left(\mathrm{C}_{3}\right.$ species $)$. As can be seen in Figure 4 , species-specific differences in $\mathrm{k}_{\mathrm{c}}$ values

265 were not easily discernible when viewed over the full year of 2011. Seasonal variation is likely

266 explained by changes in environmental or soil-moisture conditions and whether the plant was

267 transpiring under well-watered conditions, or was under water-stress (i.e. CAM cycling).

268 Average seasonal $\mathrm{k}_{\mathrm{c}}$ values are summarized by species in Table 2 for the three different green

269 roof succulent species for 2011 and 2012. Values for $\mathrm{k}_{\mathrm{c}}$ in 2012 were similar to those in 2011,

270 except for $\mathrm{k}_{\mathrm{c}}$ for P. kamtschaticus; this could indicate that the plants of this species were not as

271 fully established in 2011 as we thought, or perhaps the species had a different physiological

272 response to the environmental conditions for that year (Annandale and Stockle 1994). Our data

273 on plant coverage for this species (Starry 2013) indicate the former explanation may be more

274 likely. Species-specific differences were more evident as well as statistically significant in 2012. 
3.4 Using ET equations to estimate VWC and the 2012 water balance:

During 2012, $676 \mathrm{~mm}$ of rain were recorded including $165 \mathrm{~mm}$ during tropical storm Sandy at the end of October. Excluding this outlier rain event, runoff totaled 289, 285, and 226 mm for S. album, S. sexangulare, and P. kamtschaticus treatments respectively. Differences in $\mathrm{E}_{\mathrm{T}}$ among species were significant (Starry 2013). In 2012, the highest total $\mathrm{E}_{\mathrm{T}}$ was $184 \mathrm{~mm}$ for P. kamtschaticus, compared to180 mm for S. sexangulare and $138 \mathrm{~mm}$ for S. album. Despite less rain in 2012, total rates of $\mathrm{E}_{\mathrm{T}}$ for 2011 and 2012 were similar, perhaps reflecting increased plant root density, leaf area and the associated plant water utilization.

We compared the ability of the FAO Penman Monteith equation, adjusted for a variety of $\mathrm{k}_{\mathrm{c}}$ values, to predict $\mathrm{E}_{\mathrm{T}}$ from green roofs in 2012. Table 3 shows how selecting different $\mathrm{k}_{\mathrm{c}}$ values are associated with different $\mathrm{k}_{\mathrm{c}}$ predictions and associated error for different species. For example, selecting a fixed seasonal average for $\mathrm{k}_{\mathrm{c}}$ resulted in more error in $\mathrm{E}_{\mathrm{T}}$ predictions for $S$. album since this species had the most seasonally variable rates of $\mathrm{E}_{\mathrm{T}}$. Adjusting the FAO Penman Monteith equation with 2011 crop coefficients allowed for prediction of $\mathrm{E}_{\mathrm{T}}$ in 2012 to within 3-13 mm. Adjusting the equation with the average of 2011 and 2012 values did not improve predictions compared to just using 2011 values. These results might be different if data from more than 2 years were being compared. Slight adjustments in $\mathrm{k}_{\mathrm{c}}$ and $\mathrm{E}_{\mathrm{T}}$ did not have substantial impacts on the overall water balance or especially on predicted runoff. However, adjusting the $\mathrm{k}_{\mathrm{c}}$ down from 1 resulting in significant improvement in $\mathrm{E}_{\mathrm{T}}$ predictions for all species (Table 3). This also corresponded with substantial reduction in error runoff prediction. Figure 5 shows the relationship between expected and predicted $\mathrm{E}_{\mathrm{T}}$ for 2012 using average $\mathrm{k}_{\mathrm{c}}$ values for 2011 and 2012. Perhaps due to the simplification of making seasonal $\mathrm{k}_{\mathrm{c}}$ estimates, our calculations tend to over-predict low $\mathrm{E}_{\mathrm{T}}$ and under-predict high $\mathrm{E}_{\mathrm{T}}$; this is in line 
with the findings of others for using the ASCE version of the Penman Monteith equation

300 (Marasco et al. 2014). The Nash-Sutcliffe estimate comparing observed and predicting $\mathrm{E}_{\mathrm{T}}$ for

3012012 is 0.31 , indicating our predictions are a substantial improvement over the dataset mean.

302 Figures 6a-c show the predicted runoff for (a) P. kamtschaticus, (b) S. album and (c) S.

303 sexangulare using the 2012 data and $2011 \mathrm{k}_{\mathrm{c}}$ values. As shown, the simple water balance model

304 predicts runoff, in the best example, to within $2 \%$. Using the $\mathrm{k}_{\mathrm{c}}$ values derived here, $\mathrm{E}_{\mathrm{T}}$ was

305 somewhat overpredicted by the model, but this had little effect on the overall water balance

306 (Table 3). As Figure 4 suggests, the more substantial error in the model is likely attributed to

307 errors in accurately measuring field capacity, which was not the main focus of our study. This is

308 demonstrated (Figure 4) by the marked difference between observed and predicted VWC

309 immediately following a rain event. The model over-predicted FC, especially during the

310 summer months, despite our attempts to empirically adjust for this. The inability of the substrate

311 to consistently reach FC could be explained by a hysteresis of the wetting curve for our substrate

312 (Perelli 2014), which had a substantial clay content. This phenomenon could also be explained

313 by a lack of low-intensity (i.e. long) saturating rainfall events, coupled with higher canopy

314 interception, and possibly also hydrological 'channeling' and preferential stem flow (She and

315 Pang 2008).

316 Conclusions:

317 This study clearly illustrates that once appropriate crop coefficients are established the

318 FAO56 Penman Monteith equation, when properly parameterized, can accurately predict $\mathrm{E}_{\mathrm{T}}$ for

319 green roof species, and it can be adjusted to account for both variations in soil moisture and plant

320 water use on a daily or seasonally-adjusted basis. We have identified and provided some insight

321 into how accurate $\mathrm{k}_{\mathrm{c}}$-values should be estimated for different succulent species exhibiting CAM 
322 physiology, especially given that plant water use can be significantly over-estimated. This

323 increased precision is absolutely necessary for reflecting meaningful rates of $\mathrm{E}_{\mathrm{T}}$, especially when

324 considering the multiplicative effects for predicting stormwater runoff. Long-term estimates of

$325 \mathrm{k}_{\mathrm{c}}$ values, accumulated over many years for different green roof plant species in different

326 environments, along with observations about plant characteristics associated with $\mathrm{k}_{\mathrm{c}}$ values, may

327 ultimately yield a more generalizable $\mathrm{k}_{\mathrm{c}}$-value for use in this equation.

Apart from a simple direct method to more accurately predict $\mathrm{E}_{\mathrm{T}}$ and model stormwater

329 runoff, the simple greenroof water balance model is a tool that will enhance the way researchers

330 can contribute to the design process (Felson et al. 2013) and assist in efforts to maximize

331 performance in varying climates. The advantage of the simple water balance model presented

332 here is the ease at which it can be run with relatively few easily-measured input parameters,

333 which can be automated at a very low cost, compared with green roof installation and

334 maintenance costs. We have shown how a water balance model can be used to predict green roof

335 runoff with $90 \%$ precision. This is very important for us to quantify runoff from roofs where

336 measuring runoff is difficult (in retrofit) or oftentimes impossible. In time, we may also be able

337 to improve predictions of green roof performance at the roof scale by measuring long-term $\mathrm{k}_{\mathrm{c}}$

338 values.

339 Perhaps the best application of models like this one is for generating new hypotheses

340 about the green roof water cycle. We have identified a challenge with our water balance models,

341 and an intriguing characteristic of this commercial green roof substrate, in that substrate field

342 capacity after a storm can be highly variable depending on antecedent conditions. More complex

343 models may need to be revisited to address this source of error in our water balance models. but

344 this will only be possible once green roof substrate parameters are more easily defined and 
345 accurately measured utilizing techniques demonstrated by Fassman and Simcock (2012). Li and

346 Babcock (2014) have provided a review of different models that could be used. Once

347 sufficiently verified, a model that predicts runoff can be utilized in situations where actual rates

348 of $\mathrm{E}_{\mathrm{T}}$ are unknown, where measurement of runoff is difficult (e.g. in retrofit situations), and

349 possibly even in the context of discussions about incentivizing the installation of green roofs.

350 We suggest that until a more complex model is verified, a simple water balance model, as

351 parameterized here, can be used to effectively estimate stormwater runoff from green roofs.

352 Ultimately green roof model predictions could be incorporated into larger scale

353 watershed models that could assist in the urban planning decision-making process. The ability

354 to quantify green roof performance at the small scale, to understand variability at the large scale,

355 has been previously been limited by complexity and cost. With recent advances in gaining real-

356 time information from sensor networks, this capability is now within the budgets for many green

357 roof installations. Having models that can predict green roof efficiency and performance

358 combined with cost-effective monitoring systems will become more important as communities

359 become more committed to stormwater management, particularly where verification for

360 stormwater efficiency allows trading of stormwater credits (DDOE 2015).

\section{5. Acknowledgements:}

363 This research was supported by funding through a United States Department of Agriculture 364 specialty crop research initiative grant (SCRI 2009-51181-05768), and a Sigma Xi grant to 365 Olyssa Starry. Both Emory Knoll Farms and Conservation Technology provided our plants and 366 greenroof supplies, respectively, at a generous discount. 


\section{References:}

368 Allen, R. G., Pereira, L.S., Raes, D., and Smith, M. (1998). "Crop evapotranspiration- Guidelines for computing crop water requirements." FAO, Rome.

Annandale, J.G., and C.O. Stockle. (1994). "Fluctuation of crop evapotranspiration coefficients with weather:a sensitivity analysis." Irrigation Science 15:1-7.

372 Baraglioli, A., Guillon, A., Kovacs, Y., and Senechal, C. (2008). "Studies on the quantity impacts of green roofs." 11th International Conference on Urban Drainage, Edinburgh,

374 Scotland, UK.

375 Burszta-Adamiak, E. and Mrowiec, M. (2013). "Modelling of green roofs' hydrologic performance using EPA's SWMM." Water science and technology : a journal of the International Association on Water Pollution Research 68, 36-42.

Butler, C. (2011). "Ecology and physiology of green roof plant communities." Doctoral Dissertation, Tufts University Department of Biology.

Carson, T.B., Marasco, D.E., Culligan, P.J., and McGillis, W.R. (2013). "Hydrological performance of extensive green roofs in New York City: observations and multi-year modeling of three full-scale systems." Environmental Research Letters 8, 024036.

Carter, T. and Rasmussen, R.C. (2006). "Hydrologic behavior of vegetated greenroofs." Journal of the American Water Resources Association October, 1261-1274.

DDOE, DC Department of Energy and Environment (2015). "Stormwater Retention Credit Trading Program.” http://doee.dc.gov/src

DiGiovanni, K., (2013). "Evapotranspiration from Urban Green Spaces in a Northeast United States City.” Doctoral Dissertation. Drexel University Department of Civil, Architectural and Environmental Engineering. 
DiGiovanni, K., Montalto, F., Gaffin, S., and Rosenzweig, C. (2013). “Applicability of Classical Predictive Equations for the Estimation of Evapotranspiration from Urban Green Spaces: Green Roof Results.” Journal of Hydrologic Engineering 18, 99-107.

Fassman, E. and Simcock, R. (2012). "Moisture Measurements as Performance Criteria for Extensive Living Roof Substrates.” Journal of Environmental Engineering. 138(8),

Feller, M. (2011). "Quantifying evapotranspiration in green infrastructure: a green roof case study." Masters Thesis, Villanova University, Civil and Environmental Engineering.

Felson, A.J., M. Pavao-Zuckerman, T. Carter, F. Montalto, B. Shuster,N. Springer, E. Stander, and O. Starry. (2013). "Mapping the design process for urban ecology researchers." BioScience 63(11):854-865.

FLL, Forschungsgesellschaft fuer Landschaftsentwicklung und Landschaftsbau (2008). „Richtlinie für die Planung, Ausführung und Pflege von Dachbegrünungen.“ Bonn, Eigenverlag.

Guswa, A.J., Celia, M.A., and Rodriguez-Iturbe, I. (2002). "Models of soil moisture dynamics in ecohydrology: A comparative study.” Water Resources Research 38 (9), 1166-1180.

Hawkins, R. H., Ward,T.J., Woodward, D.E., and Van Mullem, J.A. (2009). "Curve Number

Hilten, R.N., Lawrence, T.M., and Tollner, E.W. (2008). "Modeling stormwater runoff from green roofs with HYDRUS-1D." Journal of Hydrology 358, 288-293. 
411 Kasmin, H., Stovin, V.R., and Hathway, E.A. (2010). “Towards a generic rainfall-runoff model

412 for green roofs." Water science and technology : a journal of the International

413 Association on Water Pollution Research 62, 898-905.

414 Lazzarin, R.M., Castellotti, F., and Busato, F. (2005). "Experimental measurements and 415 numerical modelling of a green roof." Energy and Buildings 37, 1260-1267.

416 Li, Y., and Babcock, R.W. Jr. (2014). "Green roof hydrologic performance and modeling:

417 a review." Water Science and Technology. 69(4), 727-738.

418 Locatelli, L., Mark, O., Mikkelsen, P.S., Arnbjerg-Nielsen, K., Bergen Jensen, M., and Binning,

419 P.J. (2014). "Modelling of green roof hydrological performance for urban drainage

420 applications.” Journal of Hydrology 519, 3237-3248.

421 Lotteau, M. (2006). “Quantifying Interception for New Zealand Green-roofs.” Undergraduate

422 Thesis The University of Auckland, Department of Civil and Environmental Engineering.

423 Mentens, J., Raes, D. and Hermy, M. (2006). "Green roofs as a tool for solving the rainwater

$424 \quad$ runoff problem in the urbanized 21st century?" Landscape and Urban Planning 77, 217-

425226.

426 Marasco, D., Hunter, B.N., Culligan, P.J., Gaffin, S.R., and McGillis, W.R. (2014), “Quantifying

427 Evapotranspiration from Urban Green Roofs: A Comparison of Chamber Measurements

428 with Commonly Used Predictive Methods.” Environmental Science and Technology 48

$429 \quad(17), 10273-10281$.

430 Maryland Department of the Environment (MDE) 2009. "Stormwater design manual."

431 http://www.mde.state.md.us/Programs/WaterPrograms/SedimentandStormwater/stormwa

432 ter_design/index.asp 
433 Nawaz, R., McDonald, A., and Postoyko, S. (2015). "Hydrological performance of a full-scale 434 extensive green roof located in a temperate climate.” Ecological Engineering 82, 66-80.

435 Palla, A., Gnecco, I., and Lanza, L.G. (2009). "Unsaturated 2D modelling of subsurface water

436 flow in the coarse-grained porous matrix of a green roof." Journal of Hydrology 379,

437 193-204.

438 Perelli, G. A. (2014). "Characterization of the Green Roof Growth Media.” Masters Thesis The 439 University of Western Ontario Civil and Environmental Engineering Program.

440 Raes, D. Timmerman, A., Hermy, M., and Mentens, J. (2006). "GreenRoof - water balance

441 model.” K.U.Leuven University, Faculty of Bioscience Engineering, Division of Soil and

442 Water Management, Leuven, Belgium.

443 Rezaei, F. and Jarrett, A.R. (2005). "Measure and predict evapotranspiration rate from greenroof." Penn State College of Engineering Research Symposium.

445 Schneider, D. (2011). "Quantifying Evapotranspiration from a Green Roof Analytically." Masters Thesis Villanova University, Civil and Environmental Engineering.

447 She, N. and Pang, J. (2008). “A Deterministic Lumped Dynamic Green Roof Model.: ASCE

448 Low Impact Development for Urban Ecosystem and Habitat Protection Proceedings, pp. 1-14, doi: 10.1061/41009(333)14.

450 Sherrard, J.A. and Jacobs, J.M. (2012). "Vegetated Roof Water-Balance Model: Experimental and Model Results." Journal of Hydrologic Engineering 17, 858-868.

452 Starry, O. (2013). "The comparative effects of three sedum species on green roof stormwater 453 retention.” Doctoral Dissertation, University of Maryland College Park, Department of Plant Science and Landscape Architecture. 
Starry, O., Lea-Cox, J.D., Ristvey, A.G., and Cohan, S. (2014a). "Monitoring and Modeling Green Roof Performance Using Sensor Networks.” Acta Horticulturae 1037: 663-669.

457 Starry, O., Lea-Cox, J.D., Kim, J., and van Iersel, M.W. (2014b). "Photosynthesis and water use by two Sedum species in green roof substrate." Environmental and Experimental Botany

460 Stovin, V., Vesuviano, G. and Kasmin, H. (2012). "The hydrological performance of a green $461 \quad$ roof test bed under UK climatic conditions." Journal of Hydrology 414-415, 148-161.

462 't Hart, H., Eggli, U. (1995). "Evolution and systematics of the Crassulaceae." International 463 Organization for Succulent Plant Study Congress 1994, Wageningen, Netherlands, 168.

464 Thornthwaite, C. W. and Mather, J. R. (1955). “ The Water Balance.” Publications in 465 Climatology, Drexel Institute of Technology, NJ.

466 USDA, United States Department of Agriculture (1986). "Urban hydrology for small $467 \quad$ watersheds.” Technical Release 55.

468 Voyde, E., Fassman, E., Simcock, R. and Wells, J. (2010). "Quantifying Evapotranspiration $469 \quad$ rates for New Zealand green roofs.” Journal of Hydrologic Engineering 15:395-403.

470 Voyde, E. (2011). "Quantifying the Complete Hydrologic Budget for an Extensive Living Roof.

471 "Doctoral Dissertation, The University of Auckland Department of Civil and 472 Environmental Engineering. 
Table 1 Summary of different kc-values reported in the literature.

\begin{tabular}{|c|c|c|c|c|}
\hline Kc Value & Reference & $\begin{array}{c}\text { Green roof design } \\
\text { and location }\end{array}$ & $\begin{array}{c}\text { Study } \\
\text { duration }\end{array}$ & Plant type \\
\hline $0.15-0.62$ & Lazzarin 2005 & $\begin{array}{l}1000 \mathrm{~m}^{2} \text { green roof in } \\
\text { Vicenza, Italy }\end{array}$ & $\begin{array}{l}2 \text { summers } \\
\text { and } 1 \text { winter }\end{array}$ & Sedum mix \\
\hline 0.53 & $\begin{array}{l}\text { Sherrard and } \\
\text { Jacobs } 2012\end{array}$ & $\begin{array}{l}\text { Rooftop modules, } \\
\text { NH, USA }\end{array}$ & Fall Aug-Nov & Sedum mix \\
\hline $0.85-1.01$ & Voyde 2011 & $\begin{array}{l}\text { Greenhouse study, } \\
\text { Auckland, NZ (FAO- } \\
24 \text { method used) }\end{array}$ & $\begin{array}{l}\text { Simulated NZ } \\
\text { Fall } \\
\text { (March/April) }\end{array}$ & $\begin{array}{l}\text { S. mexicanum } \\
\text { and D. australe }\end{array}$ \\
\hline $0.59-0.98$ & DiGiovanni 2013 & $\begin{array}{l}\text { Single rooftop } \\
\text { module, New York, } \\
\text { NY }\end{array}$ & $\begin{array}{l}\text { Seasonal } \\
\text { average over } \\
3 \text { years }\end{array}$ & Sedum mix \\
\hline $0.80-1.44$ & $\begin{array}{l}\text { Locatelli et al. } \\
2014\end{array}$ & $\begin{array}{l}3 \text { green roof test sites } \\
\text { in Denmark }\end{array}$ & 1 year & Sedum mix \\
\hline $0.24-3.25$ & $\begin{array}{l}\text { Rezai and Jarrett } \\
2005\end{array}$ & $\begin{array}{l}\text { Greenhouse study, } \\
\text { State College, PA, } \\
\text { USA }\end{array}$ & $\begin{array}{l}6 \text { months } \\
\text { controlled to } \\
\text { simulate } 4 \\
\text { seasons }\end{array}$ & $\begin{array}{l}\text { D. nubigenum } \\
\text { and } S \text {. album }\end{array}$ \\
\hline
\end{tabular}


Table 2. Average $\mathrm{k}_{\mathrm{c}}$ values and (standard error) for three different green roof succulent species, by season. Statistically significant differences (proc mixed) within seasons are indicated by the symbol $*(p<0.01)$. Significant differences within species by season $(\mathrm{p}<0.01$, proc mixed) are labeled with different letters.

\begin{tabular}{llll}
\hline Season & S. album & P. kamtschaticus & S. sexangulare \\
\hline \hline Spring 2011 & $0.24^{\mathrm{a}}(0.03)$ & $0.25^{\mathrm{a}}(0.03)$ & $0.36^{\mathrm{abc}}(0.07)$ \\
Summer 2011 & $0.21^{\mathrm{a}}(0.02)^{*}$ & $0.28^{\mathrm{a}}(0.02)^{*}$ & $0.22^{\mathrm{b}}(0.02)^{*}$ \\
Fall 2011 & $0.39^{\mathrm{b}}(0.03)$ & $0.40^{\mathrm{ab}}(0.04)$ & $0.46^{\mathrm{ac}}(0.06)$ \\
\hline Spring 2012 & $0.32^{\mathrm{a}}(0.03)^{*}$ & $0.58^{\mathrm{cd}}(0.04)^{*}$ & $0.55^{\mathrm{c}}(0.04)^{*}$ \\
Summer 2012 & $0.25^{\mathrm{a}}(0.02)^{*}$ & $0.71^{\mathrm{c}}(0.04)^{*}$ & $0.36^{\mathrm{abc}}(0.04)^{*}$ \\
Fall 2012 & $0.50^{\mathrm{b}}(0.08)$ & $0.46^{\mathrm{bd}}(0.03)$ & $0.34^{\mathrm{ab}}(0.03)$ \\
\hline
\end{tabular}


Table 3. Estimated $\mathrm{k}_{\mathrm{c}}$ values for three different succulent species, by season in 2012, and 483 associated effects on model predictions

\begin{tabular}{|c|c|c|c|c|}
\hline $\begin{array}{l}\text { Crop } \\
\text { coefficient } \\
\left(\mathrm{k}_{\mathrm{c}}\right) \text { used }\end{array}$ & Species & $\begin{array}{l}2012 \mathrm{E}_{\mathrm{T}} \\
\text { predicted } \\
\text { vs } \\
\text { (actual) }\end{array}$ & $\begin{array}{l}\text { Equation relating } \\
\text { predicted } \mathrm{E}_{\mathrm{T}} \text { to } \\
\text { expected* }\end{array}$ & $\begin{array}{l}2012 \\
\text { Runoff } \\
\text { (mm) } \\
\text { predicted } \\
\text { vs (actual) }\end{array}$ \\
\hline
\end{tabular}

S. album

$146(137)$

$\mathrm{y}=0.25 \mathrm{x}+0.58$

$297(293)$

\begin{tabular}{|c|c|c|c|c|}
\hline & \multicolumn{4}{|c|}{$\mathrm{R}^{2}=0.10$} \\
\hline & P. kamtschaticus & $163(176)$ & $\begin{array}{l}y=0.27 x+0.58 \\
R^{2}=0.20\end{array}$ & 278 (226) \\
\hline & S. sexangulare & $170(167)$ & $\begin{array}{l}y=0.25 x+0.66 \\
R^{2}=0.14\end{array}$ & $270(285)$ \\
\hline $\begin{array}{l}\text { Average of } \\
2011 \text { and }\end{array}$ & S. album & $160(137)$ & $\begin{array}{l}y=0.30 x+0.61 \\
R^{2}=0.13\end{array}$ & $280(293)$ \\
\hline
\end{tabular}

\begin{tabular}{llcll}
\hline & P. kamtschaticus & $205(176)$ & $\begin{array}{l}\mathrm{y}=0.54 \mathrm{x}+0.56 \\
\mathrm{R}^{2}=0.31\end{array}$ & $220(226)$ \\
\hline & S. sexangulare & $185(167)$ & $\begin{array}{l}\mathrm{y}=0.34 \mathrm{x}+0.65 \\
\mathrm{R}^{2}=0.17\end{array}$ & $250(285)$ \\
\hline $\begin{array}{llll}\text { Fixed seasonal } \\
\text { average }\end{array}$ & S. album & $187(137)$ & $\begin{array}{l}\mathrm{y}=0.29 \mathrm{x}+0.74 \\
\mathrm{R}\end{array}$ & $245(293)$ \\
& & & $\mathrm{R}^{2}=0.07$ &
\end{tabular}
$(0.38)$

P. kamtschaticus

$187(176)$

$\mathrm{y}=$

\begin{tabular}{lllll} 
& P. kamtschaticus & $187(176)$ & $\begin{array}{l}\mathrm{y}=0.42 \mathrm{x}+0.57 \\
\mathrm{R}^{2}=0.27\end{array}$ & $245(226)$ \\
\hline & S. sexangulare & $187(167)$ & $\begin{array}{l}\mathrm{y}=0.32 \mathrm{x}+0.68 \\
\mathrm{R}^{2}=0.15\end{array}$ & $245(285)$ \\
\hline $\mathrm{k}_{\mathrm{c}=1}$ & $275(137)$ & $\begin{array}{l}\mathrm{y}=1.13 \mathrm{x}+0.62 \\
\mathrm{R}^{2}=0.18\end{array}$ & $127(293)$ \\
\hline & S. album & & \\
\hline & P. kamtschaticus & $275(176)$ & $\begin{array}{l}\mathrm{y}=1.04 \mathrm{x}+0.48 \\
\mathrm{R}^{2}=0.31\end{array}$ & $127(226)$ \\
\hline & & $275(167)$ & $\begin{array}{l}\mathrm{y}=0.79 \mathrm{x}+0.74 \\
\mathrm{R}^{2}=0.17\end{array}$ & $127(285)$ \\
\hline
\end{tabular}

Note: Large storms were removed from runoff totals; $\mathrm{E}_{\mathrm{T}}$ could only be measured on days when there was no rain.

504 
Figure 1. Experimental green roof platforms

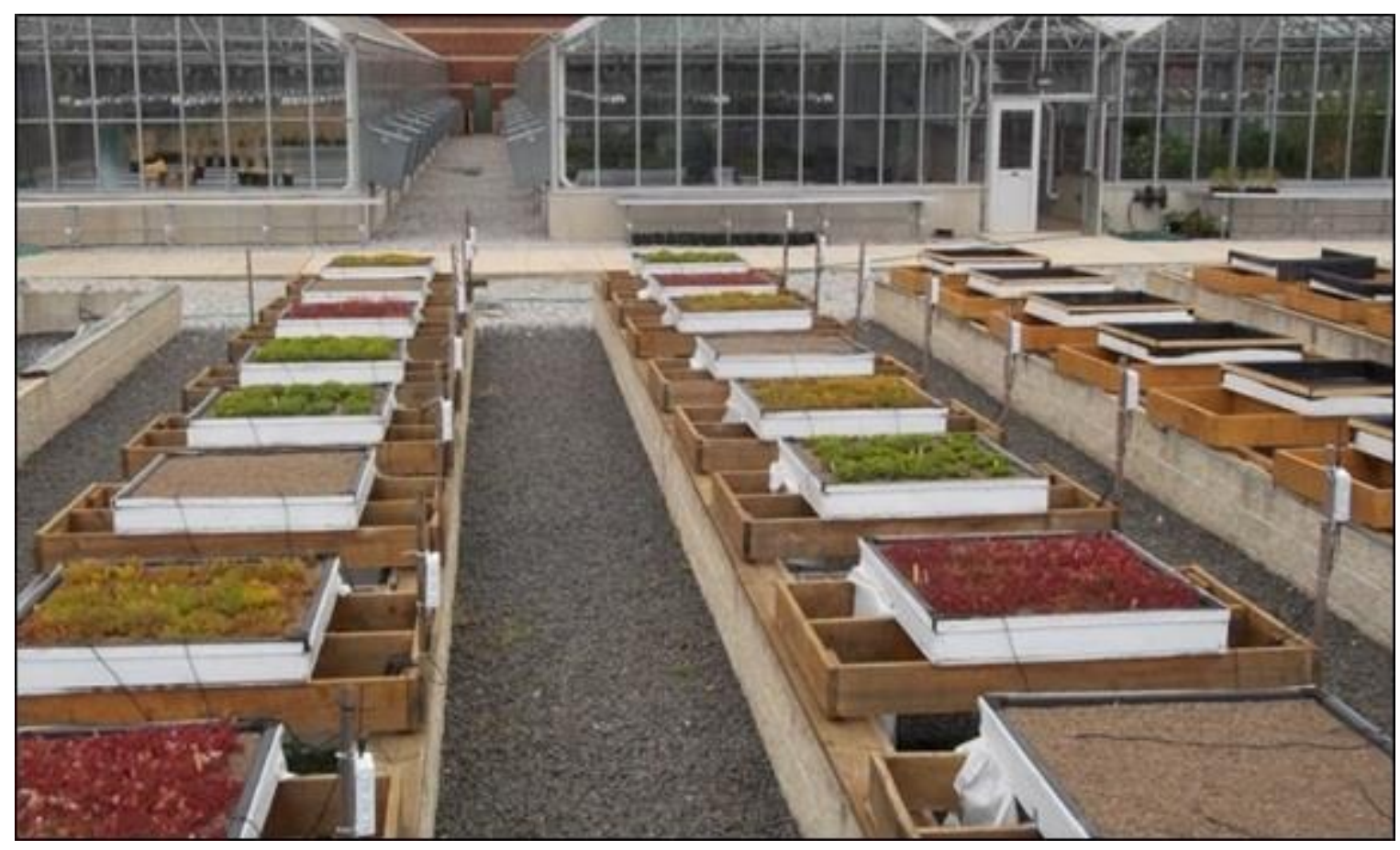

508

509 
Figure 2. Relationship between predicted and observed FC: $\mathrm{FC}=0.215+0.0005$ tdp $0.0018 \mathrm{dpe}-0.0021 \mathrm{adt},\left(\mathrm{R}^{2}=0.44, \mathrm{p}<0.001\right)$.

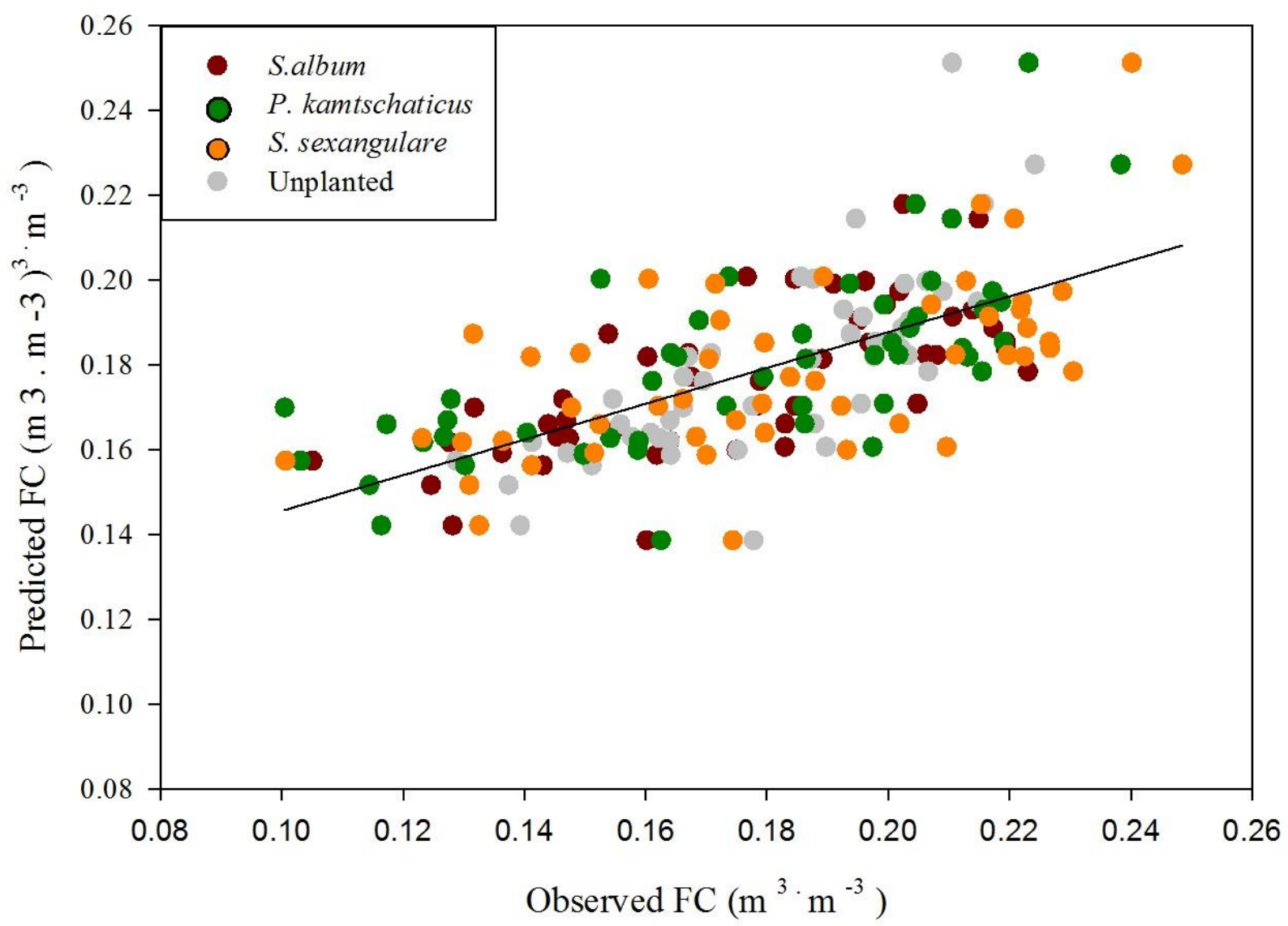

510

511 
Figure 3a-c Calculated $\mathrm{E}_{\mathrm{T}} \mathrm{O}$ and actual measured $\mathrm{E}_{\mathrm{T}}$ in 2011 for experimental green roof platforms planted with (a) Sedum album (b) Phedimus kamtschaticus, and (c) Sedum sexangulare

a.
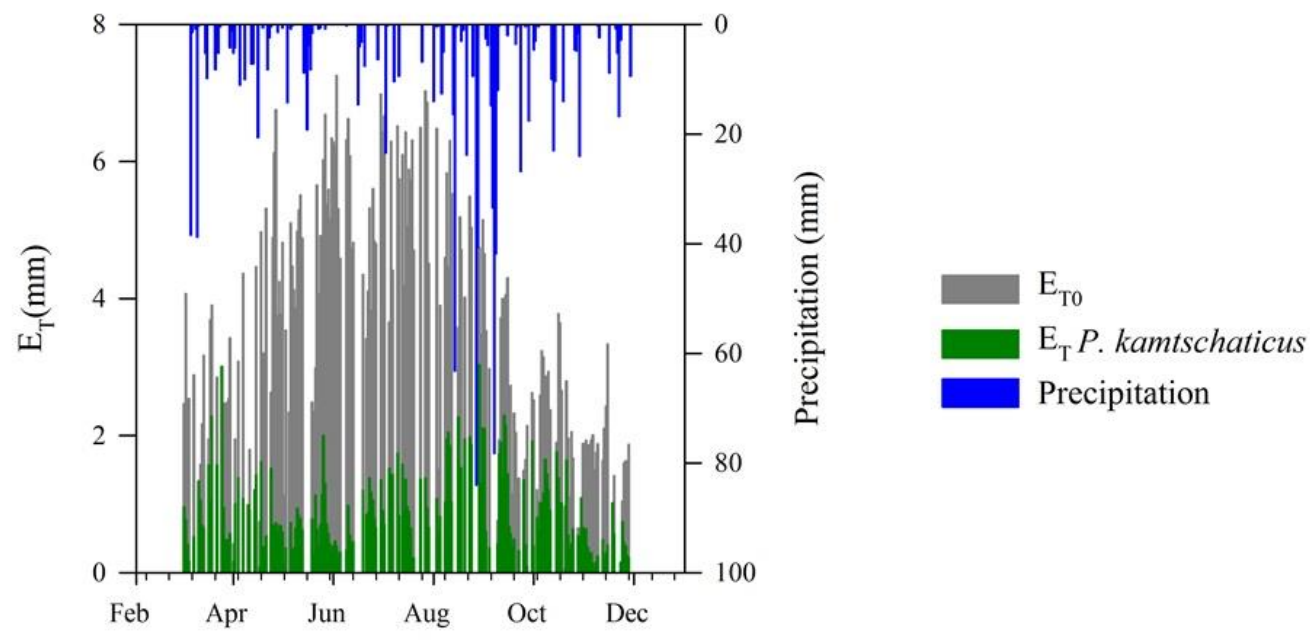

b.

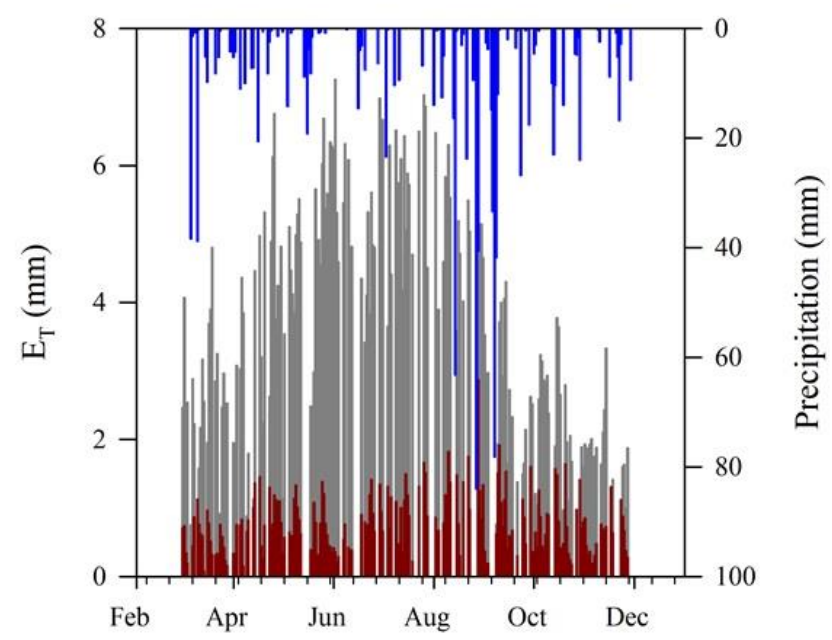

$$
\begin{aligned}
& \mathrm{E}_{\mathrm{To}} \\
& \mathrm{E}_{\mathrm{T}}(\text { S. album) } \\
& \text { Precipitation (mm) }
\end{aligned}
$$

c.

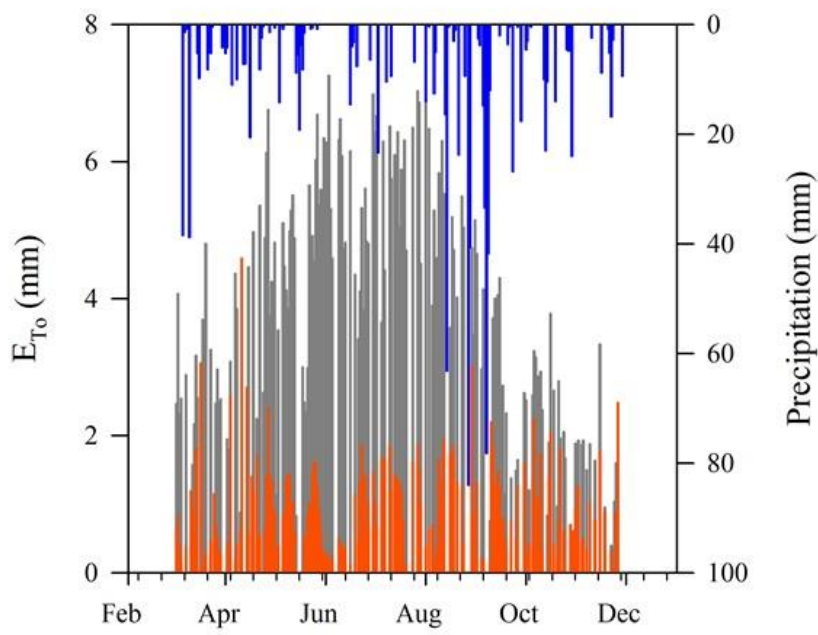


Figure 4. Estimated daily $k_{c}$ values for each species for non-rainy days during 2011.

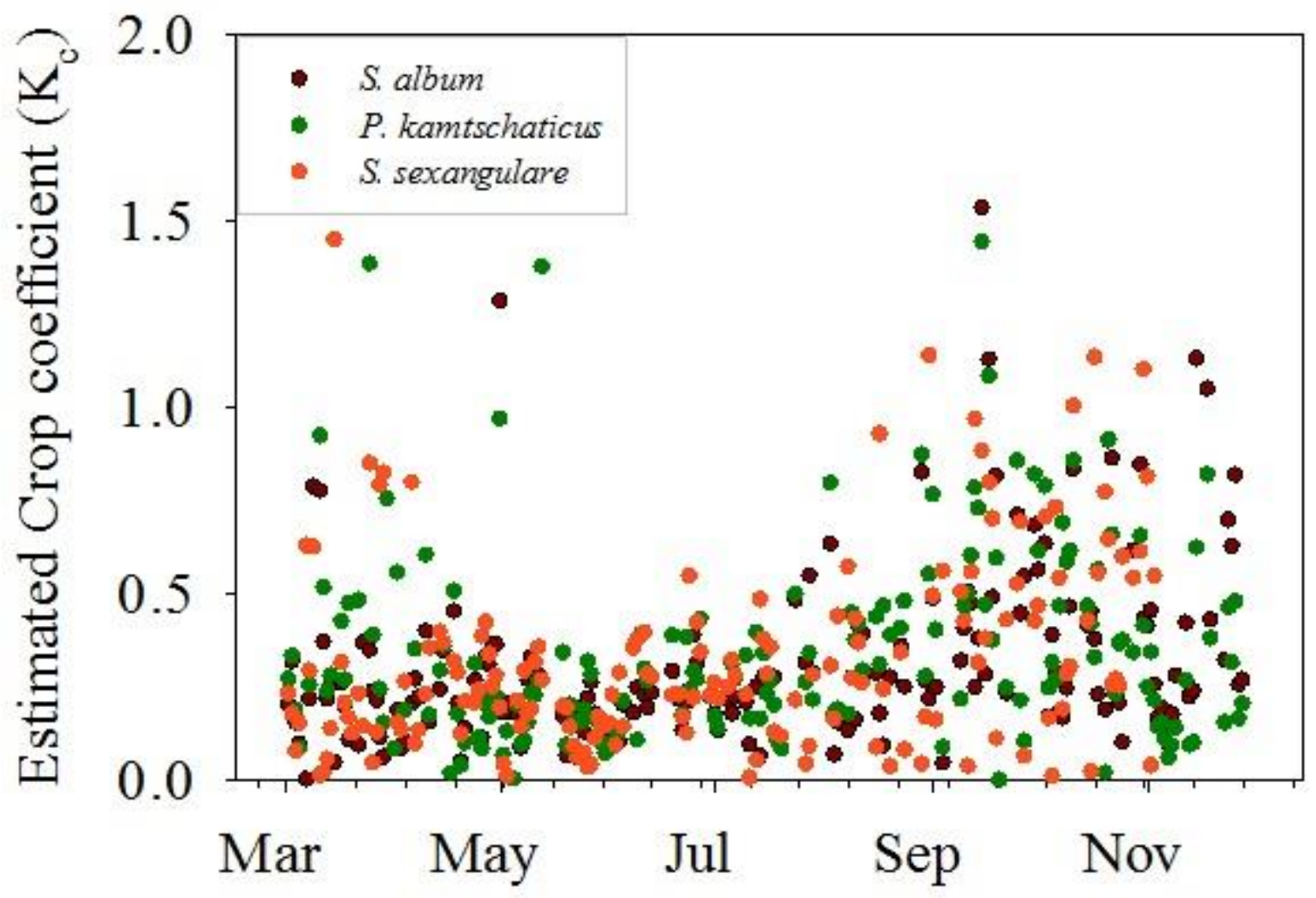

512

513 
Figure 5a-c Incorporating $\mathrm{E}_{\mathrm{T}}$ estimates into the green roof water balance model to predict stormwater runoff for (a) S album and (b) P. kamtschaticus and (c) S. sexangulare.

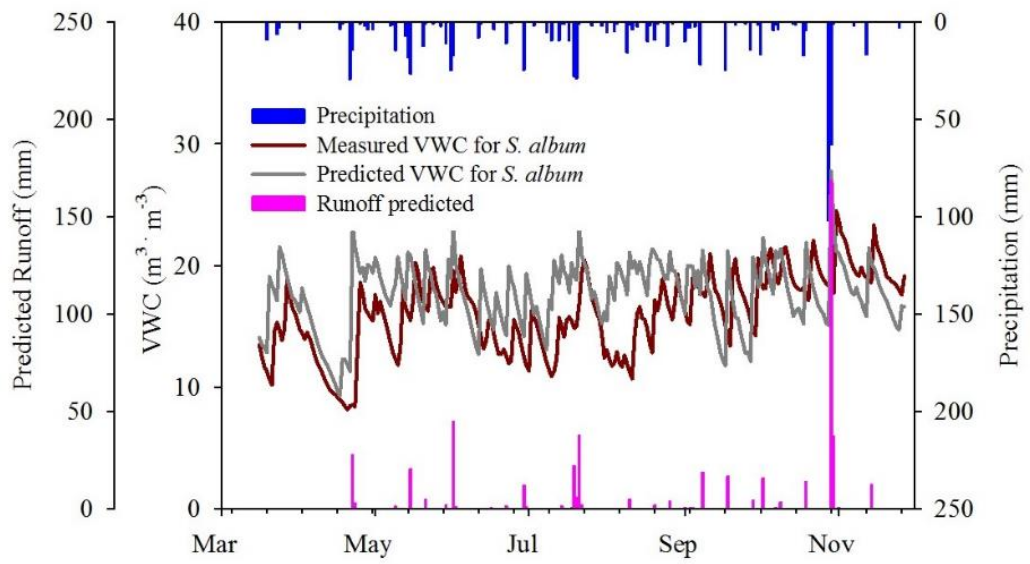

b.

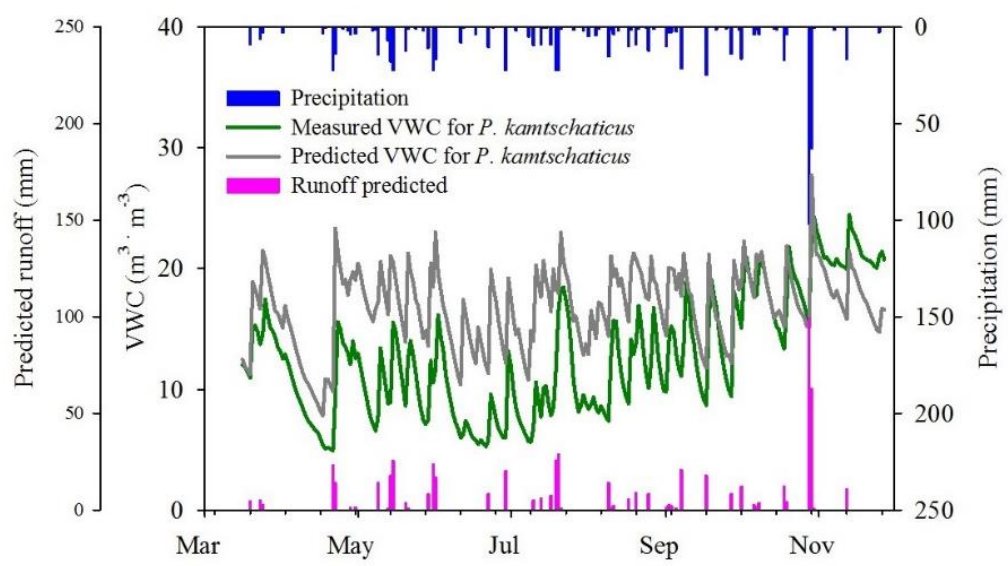

c.

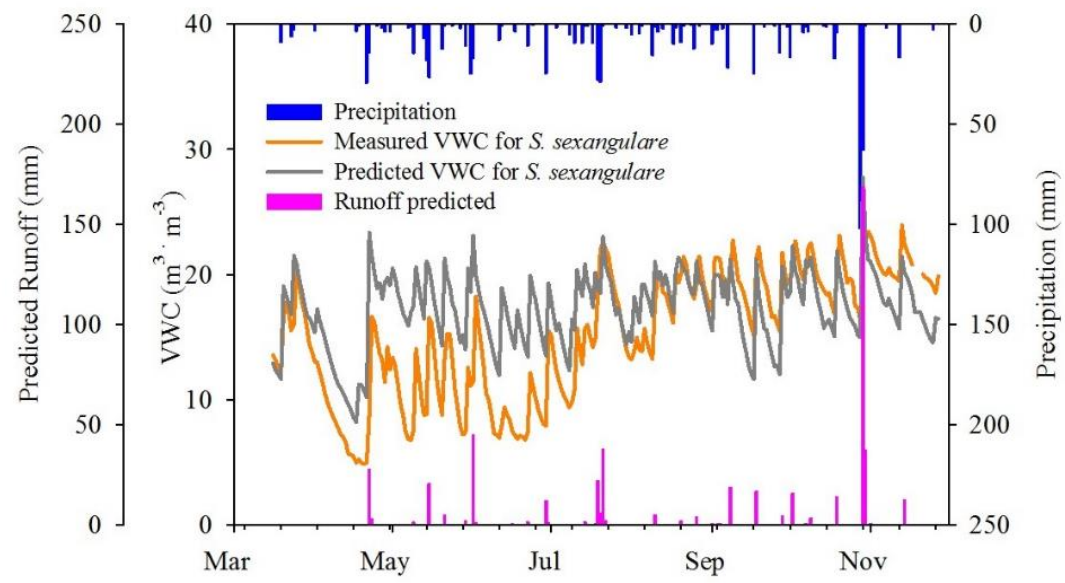


514

515 